By RICHARD D. ALTICK

\title{
The Scholar's Paradise
}

Dr. Altick is professor of English, Ohio State University.

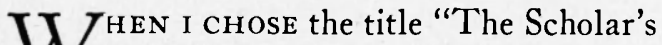
Paradise" for the remarks that are to follow, I had in mind a sentence in a letter written by one scholar to another-Erasmus to Bishop Fisher, more than four centuries ago: "I know how busy you are in your library, which is your paradise." The university and research libraries which you ladies and gentlement represent are, at least potentially, the closest thing to paradise which the genuinely devoted humanistic scholar wishes in his mortal life. They are the precincts where he meets the intellectual challenges that are the essence of his professional existence, and where, if conditions are right, he emerges victorious. My instructions have been to give you my personal views on what the right conditions are; how, in other words, you as librarians can make the scholar's hunting grounds still happier.

Speaking strictly for myself, I should say that to be a scholar's paradise, a research library should have the following features. The scholar's working quarters should, first of all, be comfortable, and it would not hurt too much if they verged on the luxurious. I would be willing to settle for the interior appointments and immediate surroundings of, say, the Houghton Library at Harvard, or the Folger, or the Huntington. I have never held with the theory that the brain works better when the body is uncom-

\footnotetext{
* Paper presented at a meeting of the University Libraries Section, ACRL, Minneapolis, Minn., June 22, I 954 .
}

fortable. Therefore I should expect to have my working quarters perfectly air-conditioned, and in order to counteract the temptation to sleep, which the soft armchairs and the lovely enveloping silence bring with them, I recommend that a touch of benzedrine be wafted through the air-conditioning system.

Now in this idyllic environment, what happens? Well, suppose I, being deep in my researches, have a sudden whim to see a book that might possibly contain a sentence of value to me. I do not stir from my chair; instead, I murmur the author and title into an intercom box that is placed inconspicuously by my side. Within no more than thirty seconds, the book slides silently onto my table, borne hither by a velvet-lined conveyor belt. There is never, you see, any necessity for my going to the bother of consulting a card catalog, let alone of my chasing the book on my own two feet. The intercom system is a sort of all-purpose lamp, which the genie-scholar need only rub to have his wishes amply filled. In addition to supplying every book he needs, it also answers every question that enters his mind in the course of his working day. For this function, it must be connected with the reference department, where a dulcet-voiced and omniscient librarian is always primed to deliver the answer the scholar needs as soon as he has finished phrasing his query, no matter how recondite it may be.

Finally, just as the mellow chimes hidden in the trees outside announce four o'clock, the door to our scholar's cell quietly opens, and in glides a troupe of lightly-clad houris 
bearing refreshments suitable to the hour. Since the long hard day of research is now over, we will draw the curtain at this point, with just one footnote in passing. There is a lot of talk nowadays about electronic gadgets eventually replacing human effort in all research. We scholars view the prospect with equanimity, for we are no enemies to labor-saving devices, especially when the labor they save may be our own. But it would be rather a shame, I think, to mechanize research so completely that the diaphanously-garbed houris would be thrown out of work.

As I said when I embarked on this perhaps too highly colored dream of paradise, the views expressed are strictly my own. Some of my colleagues would be able to dispense with the air-conditioning and even some few, possibly, with the cocktails. But every one of us would agree, for fairly obvious reasons, that the sine qua non of any scholar's paradise is books, books in infinite abundance. Now I know very well what chills such a statement must send through you. I know pretty much about your eternal struggles with budgets, the rising cost of processing new acquisitions, and the really formidable problem of housing all the books you acquire. I know that you have been busy for many years trying to work out formulas, such as the Farmington Plan, for solving these problems, and doubtless you are hungrily hoping that I will take you off the hook by offering some new ideas. Alas, I can summon up no words of wisdom, much as I wish I could. I have only two things to say. One is that every wellinformed user of research libraries sympathizes with you in your increasingly desperate dilemmas. If you often feel that you don't get enough understanding from scholars, I wonder if the reason may be that you haven't sufficiently publicized your problems so that everyone in your academic circle-not merely the administration-is aware of what you are facing. The other thing is that scholars would not be scholars if they didn't expect a library to contain, and have immediately available, every book they will conceivably ever have occasion to glance into. We are no doubt unreasonable, but give us credit for being idealists.

I can speak with some feeling on this second point, because for the past six or eight years I have been working on a research project that has required me to use literally thousands of books that seemingly nobody else has needed to look into. They have not been rare books in the ordinary sense, but simply books in fields which have not been much cultivated by scholars-the reports of certain nineteenth-century Parliamentary inquiries, obscure Victorian memoirs, the files of the Publishers' Circular and of English librarians' periodicals. Until I came along, with the design of writing a history of the mass reading public in nineteenth-century England, these books had been undisturbed for fifty or a hundred years. To some librarians they would represent dead wood, which only a high sense of professional responsibility has saved from being thrown out to make room for more "useful" items. To me as a researcher, they have been manna, albeit often dusty and dry. And there could be no more fitting occasion than this on which to invoke a comprehensive blessing on all the librarians who bought and cataloged and gave precious shelf space to those thousands of obscure books. They had faith that some time, no matter how far in the future, somebody might want to use those books; and that somebody happened to be me.

This brings me to another, but not unrelated, point. As the library profession has grown more specialized and complicated it has lost touch to some extent with the people it serves. I should like to urge that 
the best way of closing this gap is to encourage more librarians to have a broad training and a continuing interest in subject areas. I am the last person to underestimate the value of specialized library training. But just as it is absurd and dangerous for our teachers to be given an overdose of "methods of education" at the expense of true knowledge, so is it undesirable for librarians, however fine their technical equipment, to be ignorant of the special problems of the researchers they are in business to help. It is especially regrettable that so many people in the top echelons of libraries have had no personal experience in humanistic research. With the best will in the world, they cannot possibly see things as the scholar sees them, any more than a school superintendent with a doctor's degree in educational administration but no classroom experience can adopt the viewpoint of the ordinary teacher.

By laying more emphasis on a liberal postgraduate education, with generous allowance for first-hand experience in scholarly routine, you can make a good start toward breaking down the unfortunate lack of understanding that often exists between the management of libraries and the customers. But such training has an even more practical value in the case of the men and women who work in reference rooms and specialized graduate reading rooms. On the staff of every large research library there should be at least a few persons whose major training has been, not in library science, but in the various fields of the humanities and social sciences. These people should not only have had extensive personal experience in research, but even more important, they should be expected to keep up with all the latest developments in their fields, such as the appearance of new reference works and bibliographies. I have good reason to know how valuable such librarians are to the scholar, because time after time a question addressed to the right individual has resulted in a short cut to material of which I was entirely ignorant, or which I could have come across only through a long and timewasting process of investigation. I can suggest nothing which would earn you warmer gratitude from practicing scholars than multiplying the number of well-informed, alert, and ingenious reference librarians who can talk to the researcher in his own language and help fill in the gaps which inevitably exist in his own bibliographical knowledge.

While I'm on the subject of personnel, I cannot resist touching on one matter on which I am sure all of us think alike but which is nevertheless an unnecessary source of annoyance in some libraries. Some years ago I was doing research for a book in the public library of a large eastern city. I shall cloak the library in merciful anonymity by not naming the city but merely mentioning that the street address is Fifth Avenue and Forty-Second Street. In going through the author cards referring to the works of the man I planned to write about, I found that this library, like some others that didn't use their Halkett and Laing as often as they should, had attributed to him certain books which were in fact not his. Thinking to be of some service to the library in return for the use I was making of it, I took the cata$\log$ tray to the man on duty at the information desk and said, "Would you be interested in knowing about a few false attributions in these cards?"

He looked me straight in the eye and said, "No."

I confess I was slightly taken aback, although I realize now that, to repay candor with candor, the correct reply on my part would have been, "I don't blame you a bit." The assistant's frankness was refreshing rather than irritating. But too often the 
manner of library people in dealing with their patrons is simply exasperating. I am speaking now not of department heads or other dignitaries but of the people under them-the clerks and attendants and assistants with whom the scholar has the most frequent dealings. I don't think I am being unfair when I say that many people in subordinate library posts behave toward those they are presumably there to help in a manner that would win them instant dismissal from behind the counter of any selfrespecting department store.

Let me hasten to add that I know full well that we scholars often are prima donnas; our own manner is brusque, our temperament is touchy, our demands often are excessive. I am aware that the tantrums I throw sometimes in my own university library are as deplorable as they are spectacular. But in partial extenuation I should say that I have found through considerable experience that a display of apoplectic wrath gets results in situations where patient sweetness proves of no avail. And in any case, I see no reason why the library profession as a whole should not cultivate the same tradition of undeviating courtesy, no matter how trying the circumstances, as has been built up, say, by the telephone company. The habitual discourtesy or indifference of certain library people when dealing with patrons, be they freshmen or worldfamed scholars, gives substance to the impression held by some that libraries are operated, not to be of all possible service to readers, but for the private convenience of the management. I know that such an impression is the very opposite to that which your profession seeks to cultivate, and I mention the matter now only because I have a feeling that since you yourselves have relatively little opportunity to observe the ordinary day-to-day contacts between your staff and the public, you sometimes may not be aware of the extent to which discourtesy, or, I should add, sheer incompetence helps breed misunderstanding between librarians and scholars. As I say, it is scarcely fitting for me, either as an individual or as the representative for the moment of the scholarly profession, to cast the first stone. I am sure both parties have much room for improvement.

Now for one or two other practical suggestions as to how you can smooth the way of the scholar. One relates to the processing of recent acquisitions. You all know how impatient many scholars are to receive books they have ordered from the library. On Friday they mark a bookseller's catalog or fill out cards for books reviewed in the new Times Literary Supplement, and they want to have the volumes in their hands by Tuesday at the latest. I submit that this is indefensible; they should be willing to wait, if necessary, until Thursday. But I'd like to explain why we are so eager to have books paroled from the catalogers' prison-house into our loving custody. In the case of old books, we want to see them immediately for very tangible reasons-as, for instance, we are just finishing a research paper to which they will contribute a fact or two, or we are conducting a graduate seminar that is discussing the very subject covered by those books. These reasons also hold for new books and in addition there is the desire, evident in every self-respecting professional man, to keep abreast of the newest information on the subject. No doubt the heavens would not fall if we had to put off reading that book for three months or a year, so that the catalogers could conduct their peculiar rites in a more leisurely fashion. But I am sure that all of you, whatever your personal tastes in reading, often feel the same urgency that we professional scholars do, to let not another minute go by without seeing what so-and-so says about such-and- 
such in his newly published book. I think that we should all be less admirable creatures if we were more easygoing in such respects.

Right next door to this matter of getting books on the shelves with the least possible delay is that of binding periodicals. One of the most frustrating experiences a scholar can have is to discover, when he has a list of ten articles to look up, that half of them are in periodicals whose recent numbers have been sent to the bindery. The reason why your practice often conflicts with our interests is this. In literary scholarship, as in some other fields of the humanities and the social sciences, we depend heavily for our knowledge of recent publications upon specialized serial bibliographies that come out a few months or so after the end of the calendar year they cover. These bibliographies are godsends to the busy man who can't possibly keep up with all the publications in his field as they are issued. Just about now, specialists in Victorian literature are checking over the May issue of Modern Philology, which prints a full list of the articles and books, and the reviews thereof, that have been published in their field during 1953. These men and women naturally will want at once to read the articles and important reviews that deal with topics of particular interest to them. But I wonder what proportion they will actually find on the shelves-because you librarians have sent last year's numbers of $P M L A$ and the Times Literary Supplement and Studies in Philology to be bound.

Nobody, certainly, can quarrel with your policy of binding periodicals as soon as possible. It is too bad that binding time comes just when we are especially bent upon looking at the very numbers of periodicals that are marked for binding, but nothing can be done about that. All we can ask of you is that you make every effort to reduce the time when periodicals are unavailable. Don't remove the unbound numbers from the shelves until the bindery is ready to get busy on them, and once they are in the bindery, let them have priority over other jobs. Never forget that a library's holdings are bought to be used, and every book that gathers dust in the cataloging room and every periodical that is sequestered on the binder's table reduces to that extent the library's effectiveness as an instrument of research.

One more suggestion concerning library procedure. The modern university library of course serves a highly complex purposesome of its functions having been thrust upon it by the evolving scheme of higher education, others having been more or less developed by your profession itself in its admirable eagerness to be of further service. For that reason, it is inescapable that the book-stock be distributed in a number of places in addition to the main stack. In my own university, for example, a given book may turn out to be in one of the graduate reading rooms, one of the undergraduate reading rooms, on closed reserve, in the reference room, in the bibliography room, in one of the many departmental libraries scattered over the campus, in the "stack annex" located in the men's gymnasium, or, finally, deposited in the Midwest InterLibrary Center, some 320 miles away in Chicago.

All of you can make strong arguments for such widespread distribution. The very real inconvenience it causes us scholars is no doubt outweighed by its advantages to others. But I do want to plead that decentralization of stock be held to a minimum, and that, before any transfer is made from the main stack to some other location, you satisfy yourselves that it would be for the best interests of the greatest number of library users. Do not, for goodness' sake, 
move books without adequate preliminary prayer and meditation. I have a notion that in the course of such meditation a mysterious voice-it might be that of scholars generally-might be heard suggesting that decentralization has gone too far, and that it is now time to reassemble books in one location. Until that trend does set in, however, may I beg one favor of you ; that whenever a book is shelved elsewhere than in the main stack, its current whereabouts be clearly noted on every relevant card in the public catalog. By current I do not mean its location as of 1952 , but as of this week. Keeping the catalog up to date is, I know, a difficult and expensive process; but if you must decentralize your collection. that is the least compensation you can make for the time, energy, and shoe-leather we expend in chasing down the items we find absent-without leave, as far as we are concerned-from their logical place in the stack. I have an idea, indeed, that you would find keeping the catalog up to date too high a price to pay for distribution of books, and that if we scholars had the power to enforce the rule, the present exodus of books from the main stack to every point of the campus and beyond would be slowed down, if not actually reversed.

So far I have been talking about library procedures as they affect both home scholars and visiting researchers. I should like to turn now to one or two considerations that bear primarily ufon scholars outside your own institution, which means, of course, the great majority of workers in a given field. You are constantly, and properly,' concerned with encouraging the greater use of your holdings, especially of those collections in whose strength you take particular pride. The problem boils down to one of publicity. Some of you issue periodicals in which you describe those collections as well as announce noteworthy recent acquisitions; some, in addition, communicate such news to your professional journals. This is all to the good, but it does not strike to the heart of the matter, which is to let practicing scholars themselves know what you have. Few of us regularly see the journals you issue as individual libraries, and even fewer see the Library Quarterly or the Library Journal. Unless an article on a great new acquisition in an American library is cited in one of our specialized serial bibliographies in language and literature, the chances are that we will hear about that acquisition only through the academic grapevine. As far as existing collections are concerned, Downs' American Library Resources is, needless to say, limited to those collections which have been described in print, and many other collections, though immensely valuable for research, have not been so honored. The American Library Directory supplement and Special Library Resources, because of their lack of detail and their attempt to cover every field of learning, are of little practical aid to scholars in a given field. Hence, if American Library $R e$ sources fails us, along with the several valuable books on regional library holdings which Mr. Downs and others have compiled, there is really no good way for a scholar working on a particular project to discover where the richest pay-dirt is hidden.

How, then, can you let researchers know what you have to offer them? My principal suggestion is that you use the channels of communication already well established in the various areas of scholarship-the learned journals and the more informal newsletters that keep people with like interests informed of recent happenings in their field. I should think that the editors of learned journals would welcome short communiqués reminding their readers that in your university library there is a fine collection of rare books or manuscripts which has not been extensively utilized as yet. For example, a couple of years ago the leading periodical for lan- 
guage-and-literature scholars, Publications of the Modern Language Association, ran a most informative article on the holdings of the Morgan Library. As for the newsletters, I can speak with some authority about one, which, in atonement for some unknown sin, I edit. The Victorian News Letter goes twice a year to between 400 and 500 scholars who are specially interested in nineteenth-century English literature. I make a particular point of including notes on recent library accessions in our field, as well as more formal articles on certain strong collections. Last year, for instance, the News Letter contained a detailed account of the Huntington's rich collection of Victorian books and manuscripts, and in the near future I hope to print similar articles on the Newberry, the Folger, the University of Texas, and other rich collections.

I strongly recommend, therefore, that you take the initiative in publicizing your holdings to the people directly concerned, through the media which they are most likely to see. I hereby invite you to let me personally know of holdings you wish Victorian scholars to know about. As for other fields, why not ask the advice of the best men on your own campuses as to the journals and newsletters which would be most likely to serve your purpose? Failing that, I'd suggest that you write to the secretary of the national professional association in each field. In that of the modern languages and literatures, write to the secretary of the Modern Language Association in New York; or consult the directory of addresses in the annual directory number of $P M L A$ for a list of journals and newsletters in whose pages you might spread the glad tidings. You have a definite responsibility to let us know much more than we at present can about your strong collections and your important acquisitions.

Your anxiety to have your special collec- tions more intensively used is the brighter side of a coin to whose darker side I must now reluctantly refer. Although the subject is a very touchy one, I should be unfair both to you and to my own profession if I did not speak of it. I allude to the practice of withholding certain materials, principally manuscripts, from the use of everyone but some privileged person who has successfully asserted his right to a monopoly. A colleague of mine, with whom I discussed my intention of mentioning the subject to you and who because of the nature of his own research has had wide and bitter experience in the matter, bluntly described the practice as a national scandal. He went on to mention certain libraries which are particularly notorious in this respect.

I do not think any library is justified in assenting to what may well be called the squatter's rights theory of research property. I make one exception, which I think is fair enough. A faculty member who has materially aided in the acquisition of a certain collection is entitled to first crack at its contents-provided, and it is an indispensable proviso, that he use it within a reasonable time. After the expiration of that time, the collection should be thrown open, with as few restrictions as possible, to any serious and sufficiently qualified scholar.

As matters stand now, far too many collections are sewed up indefinitely simply because some powerful local faculty members hope some day to write great books with the help of their contents. The motive may be even more selfish than that, it may amount to nothing more than a desire to keep out of other people's hands what a man is unable or disinclined to use for himself. Even if the more charitable interpretation of motive is the correct one, too often the result is that one man's expressed intention of using a collection "some day" denies that collection to a score of other scholars who are ready and eager to share its riches. 
I am aware that as librarians who must play ball with teaching members of the faculty, you are in a difficult position. You may also feel that a certain scholar with whom you lunch at the Faculty Club is perfectly sincere in his plans for that eventual "great book." But I need hardly remind you that university campuses are paved with good intentions.

Your obligation, I think, is clear. It is not an obligation to acquiesce in what, when all is said and done, is a deed of selfishness. Your obligation is a higher one, for it is to the world of learning in general. Modern scholarship has no room for closed deer parks, and modern librarianship should resist being called upon to protect game that is the property of scholars in general for the private interest of a handful of selfish men. By putting up "No Trespassing" signs over certain collections, you are betraying the lofty ideals to which your profession is dedicated.

As I say, there are circumstances under which temporarily limiting access to a body of manuscripts or other material is legitimate. But I stress the word temporarily. You cannot, in good conscience, continue to stand guard over those treasures after the privileged one has shown no inclination to profit by his advantage. Hence, despite the difficulties and the very real prospect of personal bitterness involved, I beg you to cleanse your libraries of the shame of tolerating dogs in the manger.

I have used forthright language in speaking of this unpleasant subject because I think it deserves to be dealt with bluntly. For the assumption underlying your invitation to me is that we are all engaged in a common enterprise, the end of which is the extension of human knowledge. Your job is not only to collect but to make available the materials of scholarship; ours is to make use of it for the best interests of society.
You can do without us, and I have no doubt at all that many times our unreasonable demands, our failure to appreciate your side of an issue, impel you to feel that you could do without us very well indeed. But we cannot do without you. It is no exaggeration to say that the whole edifice of modern scholarship rests upon the foundation of your libraries. In the past few years I have had occasion to dig pretty deeply into the history of librarianship in England and America in the past century or so, and one aspect above all has impressed me. That is the stirring transformation which has occurred in the attitude of the profession generally toward its place in society and toward its clients. A hundred years ago, fifty years ago, even less time than that, most librarians were, to say the least, suspicious of their readers. Books were to be guarded, not to be freely dispensed to applicants. Libraries were treasure-houses, but the arrangements for the use of those treasures were roughly similar to those in effect in Fort Knox.

Today, with the one regrettable exception of which I have just been speaking, that attitude is no more. Recognition of the partnership of librarian and scholar is all but complete, and that recognition, I believe, is as strong on one side as on the other. What remains is to make our partnership more effective; to see each other's aims and problems more clearly, and to oil the ma. chinery by which librarianship serves the needs of research. I hope that the observations I have made in the course of this talk will contribute their mite toward this end. The scholar has not yet entered into his heavenly city, but he is coming closer and closer to it. It is within your power-with the by no means negligible help of the people who approve your budgets- to turn his vision of paradise into a vision of happy reality. 